\title{
Implication of microRNA regulation in para-phenylenediamine-induced cell death and senescence in normal human hair dermal papilla cells
}

\author{
OK-KYU LEE ${ }^{1 *}$, HWA JUN CHA ${ }^{1 *}$, MYUNG JOO LEE ${ }^{1}$, KYUNG MI LIM $^{1}$, JAE WOOK JUNG ${ }^{2}$, \\ KYU JOONG AHN ${ }^{2}$, IN-SOOK AN ${ }^{1}$, SUNGKWAN AN ${ }^{1}$ and SEUNGHEE BAE ${ }^{1}$ \\ ${ }^{1}$ Korea Institute for Skin and Clinical Sciences and Molecular-Targeted Drug Research Center, Konkuk University, \\ Seoul 143-701; ${ }^{2}$ Department of Dermatology, Konkuk University School of Medicine, Seoul 143-729, Republic of Korea
}

Received June 11, 2014; Accepted February 26, 2015

DOI: $10.3892 / \mathrm{mmr} .2015 .3487$

\begin{abstract}
Para-phenylenediamine (PPD) is a major component of hair coloring and black henna products. Although it has been largely demonstrated that PPD induces allergic reactions and increases the risk of tumors in the kidney, liver, thyroid gland and urinary bladder, the effect on dermal papilla cells remains to be elucidated. Therefore, the current study evaluated the effects of PPD on growth, cell death and senescence using cell-based assays and microRNA (miRNA) microarray in normal human hair dermal papilla cells (nHHDPCs). Cell viability and cell cycle analyses demonstrated that PPD exhibited a significant cytotoxic effect on nHHDPCs through inducing cell death and $\mathrm{G}_{2}$ phase cell cycle arrest in a dose-dependent manner. It was additionally observed that treatment of nHHDPCs with PPD induced cellular senescence by promoting cellular oxidative stress. In addition, the results of the current study indicated that these PPD-mediated effects were involved in the alteration of miRNA expression profiles. Treatment of nHHDPCs with PPD altered the expression levels of 74 miRNAs by $\geq 2$-fold (16 upregulated and 58 downregulated miRNAs). Further bioinformatics analysis determined that these identified miRNA target genes were likely to be involved in cell growth, cell cycle arrest, cell death, senescence and the induction of oxidative stress. In conclusion, the observations of the current study suggested that PPD was able to induce several
\end{abstract}

Correspondence to: Professor Seunghee Bae, Korea Institute for Skin and Clinical Sciences and Molecular-Targeted Drug Research Center, Konkuk University, 120 Neungdong-ro, Gwangjin-gu, Seoul 143-701, Republic of Korea

E-mail: sbae@konkuk.ac.kr

${ }^{*}$ Contributed equally

Key words: para-phenylenediamine, human dermal papilla cells, microRNA cytotoxic effects through alteration of miRNA expression levels in nHHDPCs.

\section{Introduction}

Para-phenylenediamine (PPD), also known as 1,4-diaminobenzene, is a key primary precursor of the oxidative dyes used in hair coloring and tattoos $(1,2)$. However, accumulating evidence has suggested that this compound sensitizes skin to allergic reactions $(3,4)$. Further studies have identified that these allergic reactions predominantly occur due to PPD-mediated activation of dendritic cells (5). Additionally, PPD is a potential carcinogen, which was reported to increase the risk of tumorigenesis in the kidney, liver, thyroid gland and urinary bladder in mice and rats $(6,7)$. In addition, in vitro studies have demonstrated that $\mathrm{PPD}$ induced reactive oxygen species (ROS)-mediated DNA damage in uroepithelial cells and activated p38 mitogen-activated protein kinase (MAPK) and c-Jun N-terminal kinase in Chang liver cells $(8,9)$. A case report demonstrated that PPD induced severe acute hair loss in females within six days of application (10). However, it remains to be elucidated whether PPD contributes to hair loss by inducing damage to normal human hair dermal papilla cells (nHHDPCs).

MicroRNAs (miRNAs) are small (18-24 nucleotides) noncoding RNAs that repress the translation of target genes through imperfect base pairing to the 3'-untranslated region of their target mRNAs $(11,12)$. miRNAs have been reported to be key regulators of apoptosis, proliferation and differentiation (13). Regarding the role of miRNA in hair, it has been reported that the expression levels of miRNA-31 (miR-31) were upregulated in the anagen phase of the hair growth cycle and controlled the expression levels of Krt16, Krt17, Dlx3 and Fgf10 (14). In addition, miR-24 was reported to regulate the development of hair follicles by targeting the hair keratinocyte stemness regulator Tcf-3 (15). Furthermore, a previous study demonstrated that Dicer, an miRNA-processing enzyme, was essential for the morphogenesis of hair follicles (16).

The aim of the current study was to investigate the effects of PPD on cell growth, death and senescence in nHHDPCs. 
In addition, the role of PPD in the regulation of the expression profile and the mechanisms of specific miRNAs was evaluated using bioinformatics analysis.

\section{Materials and methods}

Cells and culture conditions. nHHDPCs (Innoprot, Biscay, Spain) were cultured in Dulbecco's modified Eagle's medium (Gibco Life Technologies, Grand Island, NY, USA) supplemented with $10 \%$ fetal bovine serum (Gibco Life Technologies) and $1 \%$ penicillin-streptomycin (Gibco Life Technologies) at $37^{\circ} \mathrm{C}$ in an atmosphere of $5 \% \mathrm{CO}_{2}$. PPD was purchased from Sigma-Aldrich (St. Louis, MO, USA).

Cell viability assay. Cell viability was monitored using the water-soluble tetrazolium salt (WST-1) assay (EZ-Cytox Cell Viability Assay kit; ITSbio, Seoul, Korea). A total of $5 \times 10^{3}$ nHHDPCs were seeded into 96-well plates and treated with various concentrations of PPD (0, 100, 200, 300, 400, 500 and $600 \mu \mathrm{M}$ ) for $24 \mathrm{~h}$. Following treatment, nHHDPCs were mixed with $10 \mu \mathrm{l}$ WST- 1 solution and incubated at $37^{\circ} \mathrm{C}$ for $0.5 \mathrm{~h}$. Cell viability was then determined by measuring absorbance at $450 \mathrm{~nm}$ using an iMark plate reader (Bio-Rad Laboratories, Inc., Hercules, CA, USA).

Propidium iodide (PI)-based cell cycle analysis. The cell cycle was analyzed using PI (Sigma-Aldrich) staining of DNA. nHHDPCs were plated and treated with various concentrations of PPD $(0,200,400$ and $600 \mu \mathrm{M})$ for $24 \mathrm{~h}$. Cells were then trypsinized (using $0.25 \%$ trypsin-EDTA; Gibco Life Technologies), centrifuged (3,500 x g, 2 min), washed with phosphate-buffered saline (PBS; Gibco Life Technologies) and fixed in $70 \%$ ethanol (Merck Millipore, Darmstadt, Germany) at $4^{\circ} \mathrm{C}$ for $3 \mathrm{~h}$. The fixed cells were incubated with staining solution [50 $\mu \mathrm{g} / \mathrm{ml}$ PI, $0.1 \mu \mathrm{g} / \mathrm{ml}$ RNase (Life Technologies, Grand Island, NY, USA) and $0.05 \%$ Triton X-100 (Sigma-Aldrich) in PBS] at $37^{\circ} \mathrm{C}$ for $1 \mathrm{~h}$ and then analyzed using a FACSCalibur flow cytometer (BD Biosciences, San Jose, CA, USA). The mean PI fluorescence intensity was determined based on analysis of 10,000 cells using the FLH-2 detection channel $(585 \pm 42 \mathrm{~nm})$.

Detection of cellular senescence. For the assessment of cellular senescence, nHHDPCs $\left(2 \times 10^{6}\right)$ were seeded into $60-\mathrm{mm}$ cell culture dishes and treated with 0 or $400 \mu \mathrm{M}$ PPD. Following $48 \mathrm{~h}$ of treatment, cells were fixed using Fixative solution (included in Senescence Detection kit; BioVision, Inc., Milpitas, CA, USA) and senescence-associated- $\beta$-galactosidase (SA- $\beta$-gal) activity was measured using the Staining Solution Mix, including Staining Solution, Staining Supplements and X-gal substrate for (SA- $\beta$-gal) within the Senescence Detection kit, according to the manufacturer's instructions. Cells stained for SA- $\beta$-gal were counted under a light microscope (CKX41; Olympus Corporation, Tokyo, USA) (magnification, x200) and the percentage of SA- $\beta$-gal positive cells were calculated.

Detection of intracellular ROS. Staining for ROS in cultured cells was conducted using a 2',7'-dichlorodihydrofluorescein diacetate (DCF-DA; Sigma-Aldrich) assay. Briefly, $2 \times 10^{6} \mathrm{nHHDPCs}$ were plated in $60-\mathrm{mm}$ culture dishes and treated with PPD. Following treatment for $24 \mathrm{~h}$, the cells were stained by adding DCF-DA to the culture medium to a final concentration of $20 \mu \mathrm{M}$ and then incubating for $1 \mathrm{~h}$. Distribution of the stained cell population was determined using a FACSCalibur flow cytometer.

miRNA expression profiling. In order to analyze the miRNA expression profile, nHHDPCs $\left(2 \times 10^{6}\right)$ were seeded into $60-\mathrm{mm}$ culture dishes and treated with $400 \mu \mathrm{M}$ PPD. Following $24 \mathrm{~h}$ of treatment, total RNA was purified using TRIzol reagent (Life Technologies) according to the manufacturer's instructions. Total RNA was dephosphorylated and labeled with pCp-Cy3 using an Agilent miRNA Labeling kit (Agilent Technologies, Inc., Santa Clara, CA, USA). Labeled RNAs were hybridized using a SurePrint G3 Human v16 miRNA 8x60K microarray (Agilent Technologies, Inc.) at $65^{\circ} \mathrm{C}$ for $20 \mathrm{~h}$. The miRNA expression profile was digitized using Feature Extraction version 10.7 software (Agilent Technologies). Fold changes in miRNA expression levels were determined using GeneSpring GX software, version 11.5 (Agilent Technologies).

Prediction of potential target genes of PPD-regulated miRNAs and gene ontology (GO) analysis. Potential target genes of PPD-regulated miRNAs were predicted using the DNA Intelligent Analysis (DIANA) microT-CDS version 5.0 bioinformatics tool (http://diana.cslab.ece.ntua. $\mathrm{gr} /$ ). GO of each putative target gene was identified using the Database for Annotation, Visualization and Integrated Discovery (DAVID) bioinformatics resource, version 6.7 (http://david.abcc.ncifcrf.gov). Target genes were categorized into four GO terms: Aging, skin development, apoptosis and cell proliferation. Furthermore, target gene-associated signaling pathways were determined using the Kyoto Encyclopedia of Genes and Genomes (KEGG) pathway algorithm (http://david.abcc.ncifcrf.gov/summary.jsp) within the DAVID resource.

Statistical analyses. Values are expressed as the mean \pm standard error of the mean of three independent experiments. Statistical significance was determined by Student's t-test and $\mathrm{P}<0.05$ was considered to indicate a statistically significant difference between values.

\section{Results}

PPD treatment reduces the proliferation rate of $n H H D P C s$. Previous studies reported that exposure to $>250 \mu \mathrm{M}$ and $>60 \mu \mathrm{M}$ PPD resulted in considerable cytotoxicity in dendritic cells (17) and keratinocytes (18), respectively. Therefore, the current study aimed to determine the cytotoxic effects of PPD on nHHDPCs at concentrations of 0, 100, 200, 300, 400, 500 and $600 \mu \mathrm{M}$ using a WST-1-based cell viability assay. As shown in Fig. 1, the viability of nHHDPCs was significantly reduced following exposure to PPD for $24 \mathrm{~h}$. Maximal toxicity was observed at $600 \mu \mathrm{M}$, at which concentration cell viability was reduced to $58.33 \pm 2.39 \%$ of the control value $(n=3 ; \mathrm{P}<0.05)$. The $\mathrm{IC}_{25}$ (a $25 \%$ reduction in viability) of PPD was $400 \mu \mathrm{M}$, at which concentration cell viability was reduced to $74.42 \pm 6.08 \%$ of control value $(\mathrm{P}<0.05)$ (Fig. 1). 


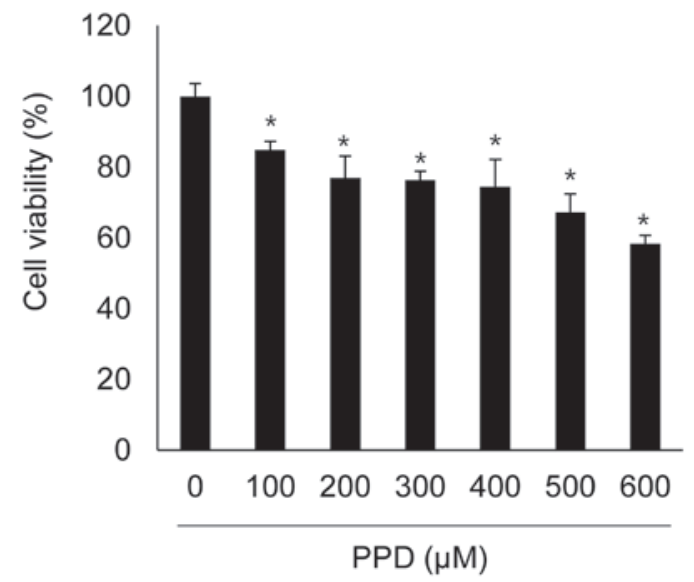

Figure 1. Effect of PPD on viability of nHHDPCs. nHHDPCs $\left(5 \times 10^{3}\right)$ were seeded into 96 -well plates and treated with various concentrations of PPD $(0,100$, $200,300,400,500$ and $600 \mu \mathrm{M}$ ) for $24 \mathrm{~h}$. Cell viability was measured using the water-soluble tetrazolium salt assay. Values are presented as the mean \pm standard error of the mean of the percentage of control optical density of experiments performed in triplicate. "P $<0.05$ vs. $0 \mu \mathrm{M}$ PPD. PPD, para-phenylenediamine; nHHDPCs, normal human hair dermal papilla cells.

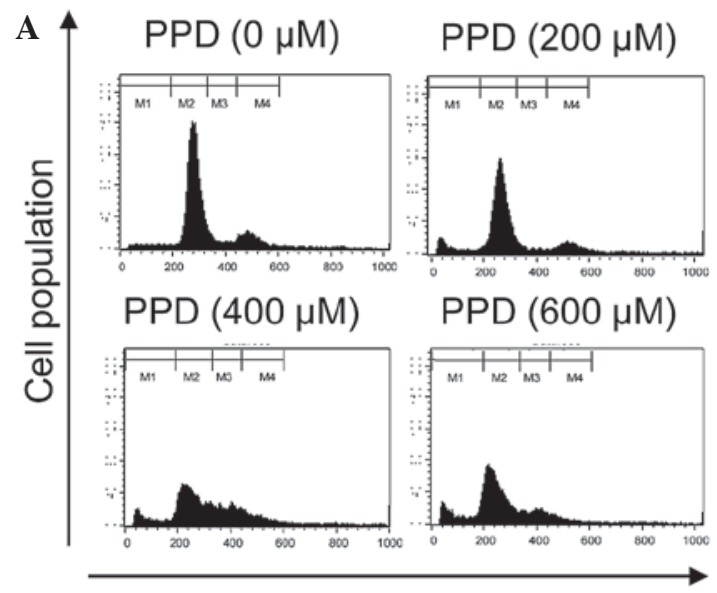

PI fluorescence intensity
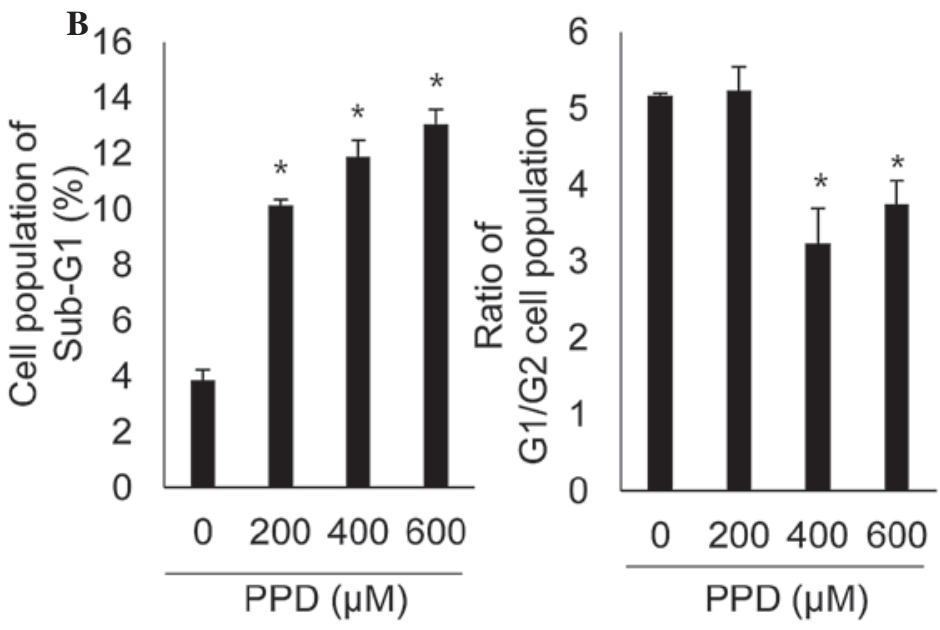

Figure 2. PPD induced cell death and $\mathrm{G}_{2}$ arrest in nHHDPCs. nHHDPCs $\left(2 \times 10^{6}\right.$ cells) were seeded into 60 -mm culture dishes, treated with PPD $(0,200,400$ and $600 \mu \mathrm{M}$ ) for $24 \mathrm{~h}$, collected and stained with PI. (A) The fluorescence-intensity distribution of the stained cells was analyzed by flow cytometry. (B) The percentage of sub- $G_{1}$ cells and the ratio of $G_{1} / G_{2}$ cells were then quantified. Sub- $G_{1}, G_{1}, S$ and $G_{2} / M$ phases were separated using gates $M 1$, M2, M3 and M4, respectively. "P<0.05 vs. $0 \mu \mathrm{M}$ PPD. PPD, para-phenylenediamine; nHHDPCs, normal human hair dermal papilla cells; PI, propidium iodide.

A

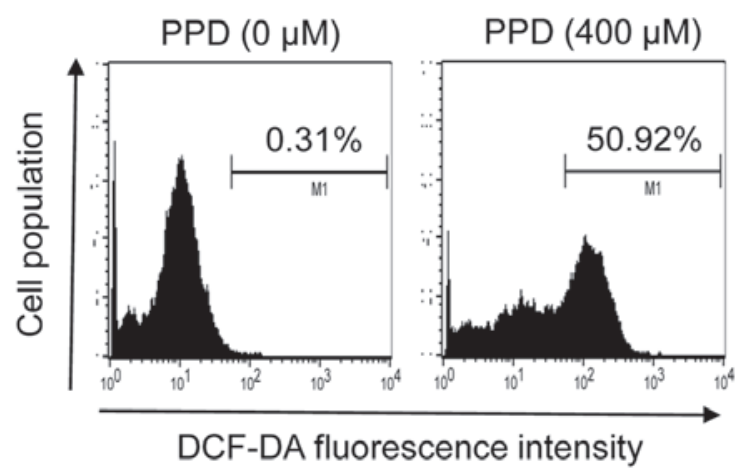

B

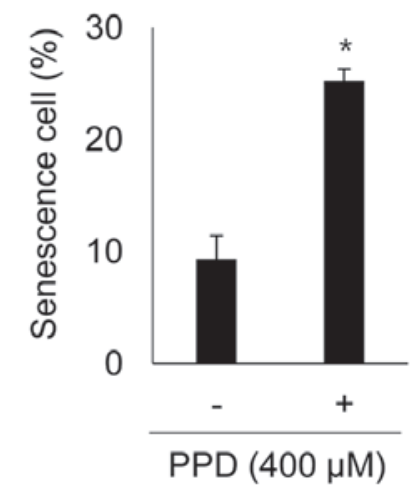

Figure 3. PPD increases intracellular ROS production and senescence in nHHDPCs. (A) nHHDPCs (2x10 ${ }^{6}$ cells) were seeded into 60 -mm culture dishes and treated with PPD $(0$ and $400 \mu \mathrm{M})$ for $24 \mathrm{~h}$. Cells were then collected and stained with DCF-DA solution. The fluorescence-intensity distribution of DCF-DA-stained cells was analyzed using flow cytometry. Alterations in the intracellular levels of ROS were determined using the M1 gate. (B) Senescence was measured using the senescence associated- $\beta$-galactosidase assay. nHHDPCs $\left(2 \times 10^{6}\right)$ were seeded in 60 -mm culture dishes and treated with PPD $(0$ and $400 \mu \mathrm{M}$ ) for $48 \mathrm{~h}$, fixed and then reacted with X-gal. "P<0.05 vs. $0 \mu \mathrm{M}$ PPD. PPD, para-phenylenediamine; ROS, reactive oxygen species; nHHDPCs, normal human hair dermal papilla cells; DCF-DA, 2',7'-dichlorodihydrofluorescein diacetate. 
Table I. MicroRNAs exhibiting a $\geq 2$-fold alteration in expression following treatment of normal human hair dermal papilla cells with para-phenylenediamine.

\begin{tabular}{|c|c|c|}
\hline MicroRNA & $\begin{array}{c}\text { Fold } \\
\text { change }\end{array}$ & $\begin{array}{c}\text { Direction of } \\
\text { regulation }\end{array}$ \\
\hline miR-100-3p & 57.90 & Up \\
\hline miR-1225-3p & 3.43 & Up \\
\hline miR-1228-3p & 2.14 & Up \\
\hline $\operatorname{miR}-1238$ & 2.34 & Up \\
\hline $\operatorname{miR}-1825$ & 2.08 & Up \\
\hline miR-18b-3p & 106.08 & Up \\
\hline miR-191-3p & 2.06 & Up \\
\hline miR-3180-5p & 100.21 & Up \\
\hline miR-33b-3p & 50.55 & Up \\
\hline miR-425-3p & 230.60 & Up \\
\hline miR-4286 & 2.03 & Up \\
\hline $\operatorname{miR}-4313$ & 2.17 & Up \\
\hline miR-4323 & 2.02 & Up \\
\hline miR-634 & 2.26 & Up \\
\hline miR-766-3p & 3.78 & Up \\
\hline miR-933 & 51.08 & Up \\
\hline $\operatorname{miR}-410$ & 2.48 & Down \\
\hline miR-513a-5p & 2.54 & Down \\
\hline miR-500a & 2.76 & Down \\
\hline miR-3651 & 3.07 & Down \\
\hline $\operatorname{miR}-1207-5 p$ & 3.14 & Down \\
\hline miR-762 & 4.29 & Down \\
\hline miR-150-3p & 15.14 & Down \\
\hline let-7a-3p & 23.13 & Down \\
\hline miR-1181 & 110.44 & Down \\
\hline miR-1226-5p & 32.72 & Down \\
\hline miR-125a-3p & 81.56 & Down \\
\hline miR-128 & 45.79 & Down \\
\hline miR-134 & 38.97 & Down \\
\hline miR-138-2-3p & 45.91 & Down \\
\hline miR-146b-5p & 30.17 & Down \\
\hline $\operatorname{miR}-148 b-3 p$ & 83.28 & Down \\
\hline miR-17-3p & 58.57 & Down \\
\hline miR-181d & 34.46 & Down \\
\hline miR-185-5p & 106.57 & Down \\
\hline miR-195-5p & 43.11 & Down \\
\hline miR-197-3p & 73.04 & Down \\
\hline miR-202-3p & 64.16 & Down \\
\hline miR-214-5p & 30.65 & Down \\
\hline miR-23a-5p & 17.14 & Down \\
\hline miR-28-5p & 50.28 & Down \\
\hline $\operatorname{miR}-301 a-3 p$ & 45.29 & Down \\
\hline miR-30a-3p & 64.02 & Down \\
\hline $\operatorname{miR}-30 e-3 p$ & 37.05 & Down \\
\hline miR-324-5p & 93.16 & Down \\
\hline miR-342-3p & 38.57 & Down \\
\hline miR-3653 & 31.43 & Down \\
\hline miR-3656 & 112.15 & Down \\
\hline miR-3663-3p & 89.50 & Down \\
\hline
\end{tabular}

Table I. Continued

\begin{tabular}{|c|c|c|}
\hline MicroRNA & $\begin{array}{c}\text { Fold } \\
\text { change }\end{array}$ & $\begin{array}{c}\text { Direction of } \\
\text { regulation }\end{array}$ \\
\hline miR-369-3p & 45.40 & Down \\
\hline miR-369-5p & 42.07 & Down \\
\hline miR-370 & 43.81 & Down \\
\hline miR-371a-5p & 15.21 & Down \\
\hline miR-378 & 36.78 & Down \\
\hline miR-3926 & 30.72 & Down \\
\hline miR-409-5p & 76.96 & Down \\
\hline miR-423-5p & 58.63 & Down \\
\hline miR-4271 & 84.01 & Down \\
\hline miR-4291 & 96.44 & Down \\
\hline $\operatorname{miR}-431-5 p$ & 50.91 & Down \\
\hline $\operatorname{miR}-431-3 p$ & 93.55 & Down \\
\hline miR-4317 & 53.97 & Down \\
\hline $\operatorname{miR}-487 a$ & 35.23 & Down \\
\hline miR-501-5p & 38.33 & Down \\
\hline $\operatorname{miR}-505-3 p$ & 30.72 & Down \\
\hline $\operatorname{miR}-513 b$ & 46.33 & Down \\
\hline miR-539-5p & 42.35 & Down \\
\hline miR-548c-3p & 19.22 & Down \\
\hline miR-572 & 29.95 & Down \\
\hline miR-642b-3p & 68.28 & Down \\
\hline miR-650 & 22.21 & Down \\
\hline miR-660-5p & 38.17 & Down \\
\hline miR-770-5p & 55.39 & Down \\
\hline miR-874 & 53.92 & Down \\
\hline
\end{tabular}

PPD treatment increases cell death and cell cycle arrest in $n H H D P C s$. The present study investigated whether PPD-induced loss of cell viability occurred due to cell cycle arrest and cell death. Cells were treated with PPD (0, 200, 400 and $600 \mu \mathrm{M}$ ) for $24 \mathrm{~h}$ and the distribution of cells in the different cell cycle phases was analyzed using flow cytometry. As shown in Fig. 2, treatment with 200, 400 and $600 \mu \mathrm{M}$ PPD led to significant accumulation in the sub- $G_{1}$ phase, compared with that of control DMSO-treated cells $(\mathrm{P}<0.05)$. In addition, the proportion of cells in $G_{1} / G_{2}$ was significantly reduced by PPD $(P<0.05)$, indicating that PPD increased the $G_{2}$ population. These data therefore demonstrated that PPD induced cell death and $\mathrm{G}_{2}$ arrest in nHHDPCs.

PPD treatment leads to the accumulation of intracellular ROS and senescence-like growth. Chye et al (8) observed that PPD increased intracellular ROS and induced apoptosis in Chang normal human liver cells. Therefore, the current study investigated the effects of PPD on the regulation of intracellular ROS production in nHHDPCs. Intracellular ROS levels were determined using an DCF-DA probe, which is oxidized to fluorescent DCF in the presence of ROS. As presented in Fig. 3A, exposure to PPD resulted in a marked increase in 


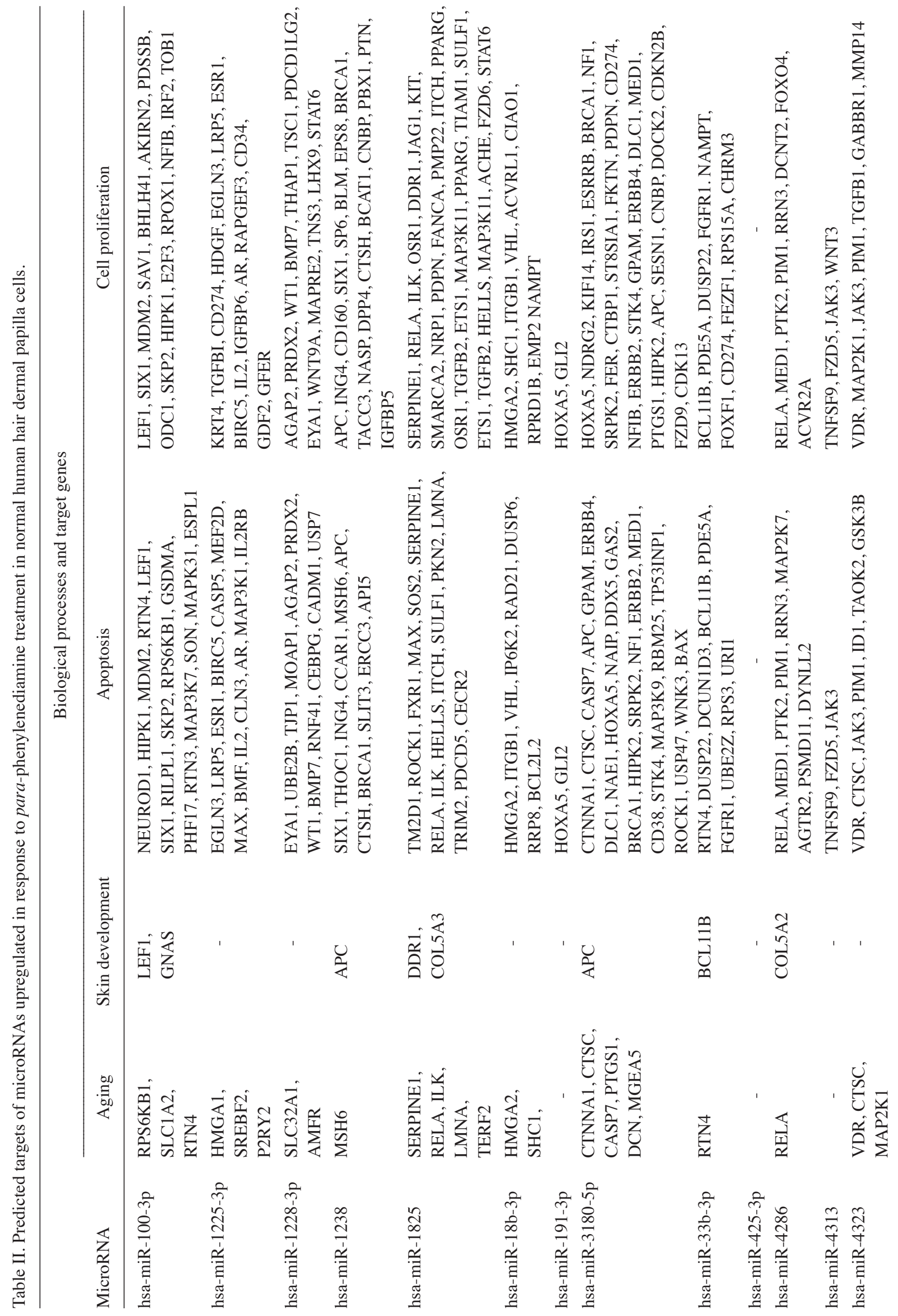


fluorescent DCF-positive cells compared with that of the control cells, indicating that PPD increased intracellular ROS production in nHHDPCs. As ROS have been implicated in cellular senescence (19), the present study investigated whether the PPD-mediated increase in ROS was associated with increased senescence by analyzing the activity of SA- $\beta$-gal, a marker of cellular senescence. Consistent with the observed ROS increase, PPD was identified to promote an increase in SA- $\beta$-gal activity (Fig. 3B), indicating that PPD induces cellular senescence in nHHDPCs.

Identification of differentially expressed miRNAs in PPD-treated nHHDPCs. Fig. 2 and 3 demonstrated that cell cycle arrest in $\mathrm{G}_{2}$ phase and PPD-mediated cell death were characterized by increased ROS production. Therefore, in order to determine whether ROS-mediated cell cycle arrest and cell death are associated with miRNA expression, miRNA microarray analysis was conducted using the SurePrint G3 Human v16 miRNA 8x60K microarray, which contained 2,006 human miRNA probes. Significant miRNAs exhibiting $a \geq 2.0$-fold increase or reduction in expression were selected using GeneSpring GX software. As presented in Table I, PPD differentially regulated the expression levels of 74 miRNAs. Notably, 16 of 74 miRNAs were significantly upregulated and 58 miRNAs were significantly downregulated. In particular, miR-425-3p exhibited the greatest increase in expression (230.60-fold) and miR-3656 the greatest reduction (112.15-fold), compared with the corresponding miRNAs in control cells. These results suggested that the PPD-mediated cellular effects were associated with alterations in expression of specific miRNAs.

Bioinformatic analysis of PPD-modulated miRNAs. As miRNAs perform their biological functions through regulation of target mRNA translation (11), the present study aimed to predict the target genes of the miRNAs deregulated in response to PPD. The biological functions of the upregulated and downregulated genes were then determined following categorization into the four groups: Aging, apoptosis, cell proliferation and skin development, using DAVID (Tables II and III, respectively). In addition, in order to identify the specific signaling pathways of the deregulated miRNAs, the correlation between KEGG pathway-associated genes and the target genes of each miRNA were analyzed. The meaningful KEGG pathways with a value $>1 \%$ (percentage of target genes/total genes involved in each pathway) were selected. The analysis identified a wide distribution of cellular functions, which are presented in Tables IV and V. The results indicated that the upregulated miRNAs were implicated in signaling pathways in cancer, ubiquitin-mediated proteolysis, melanogenesis, cell cycle, Wnt signaling, MAPK signaling, neurotrophin signaling, cell adhesion molecules (CAMs), long-term potentiation, natural killer cell-mediated cytotoxicity, calcium signaling, neuroactive ligand-receptor interactions, glycosphingolipid biosynthesis, arrhythmogenic right ventricular cardiomyopathy, axon guidance, ErbB signaling, gonadotropin-releasing hormone signaling, tight junctions and viral myocarditis (Table IV). In addition, PPD-induced downregulated miRNAs were implicated in signalingpathwaysincancer,regulationofactincytoskeleton, Wnt 


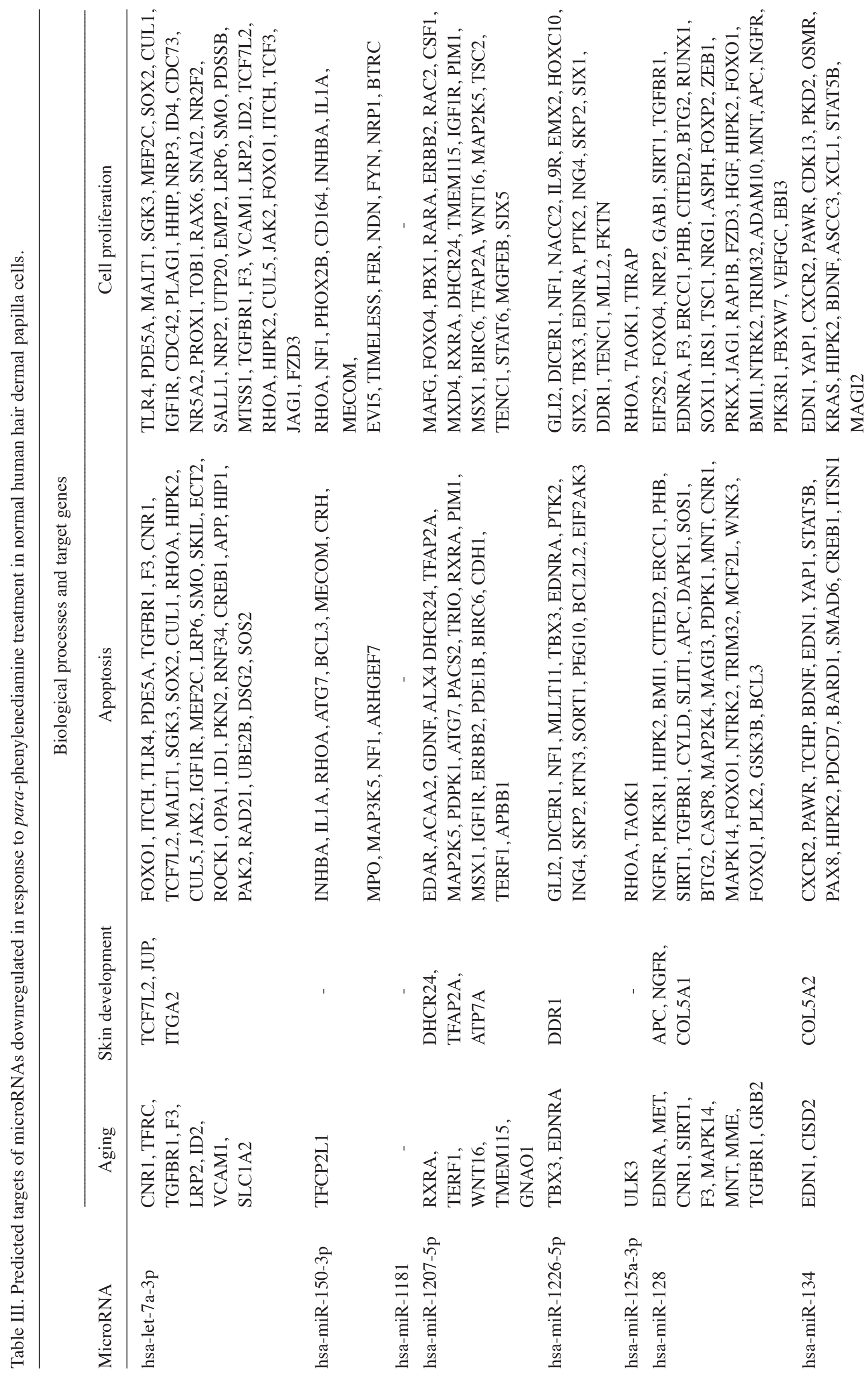




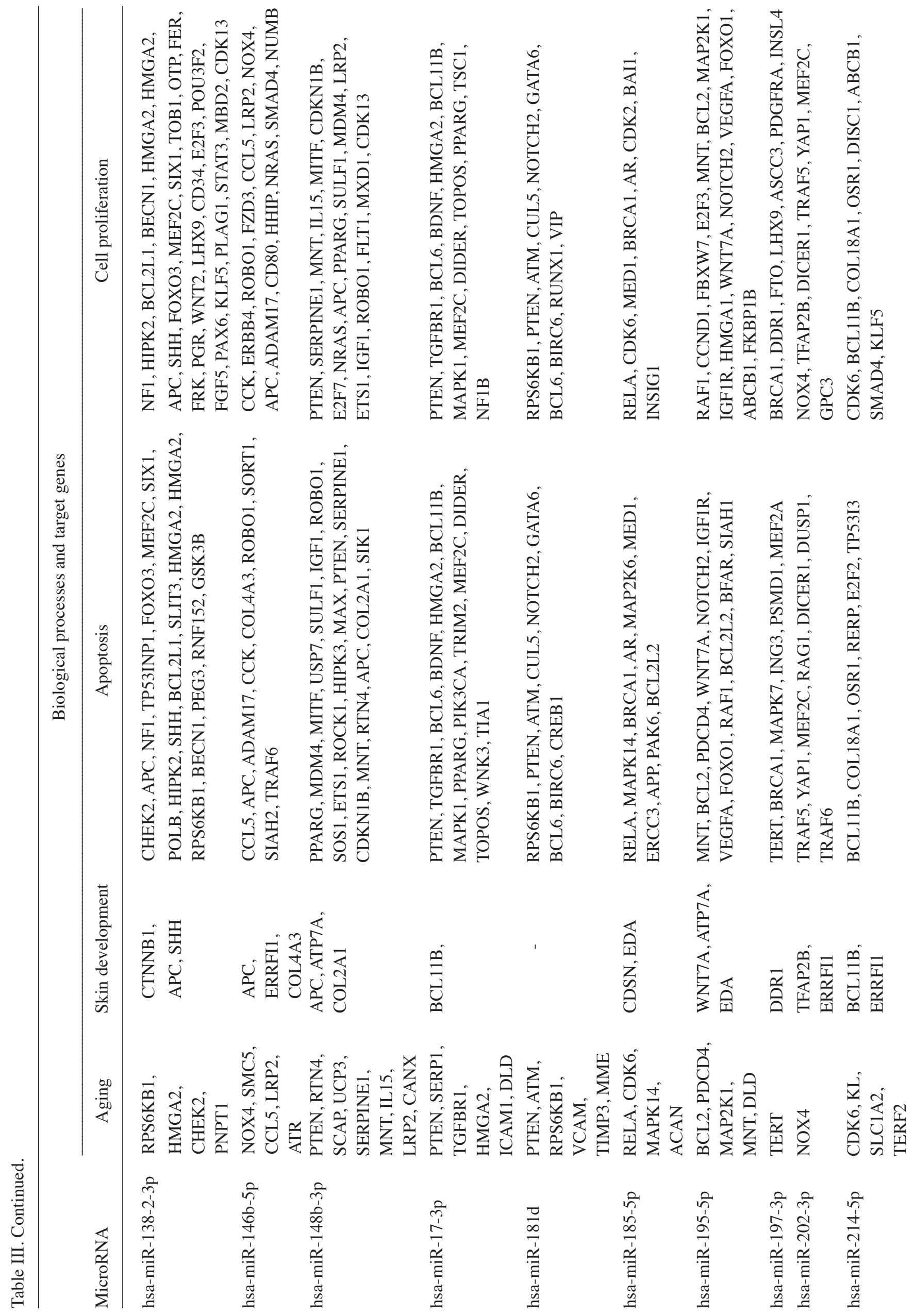




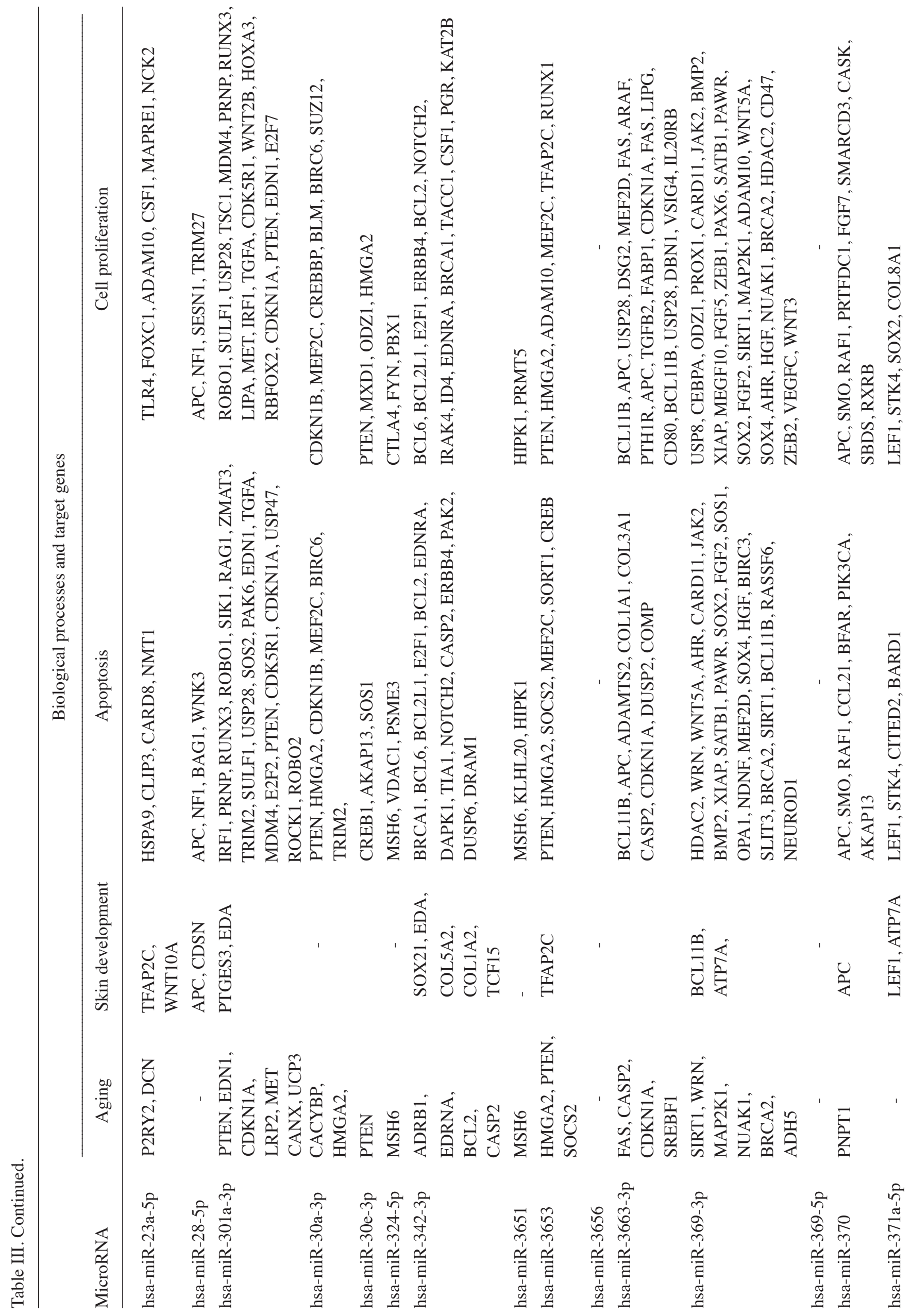




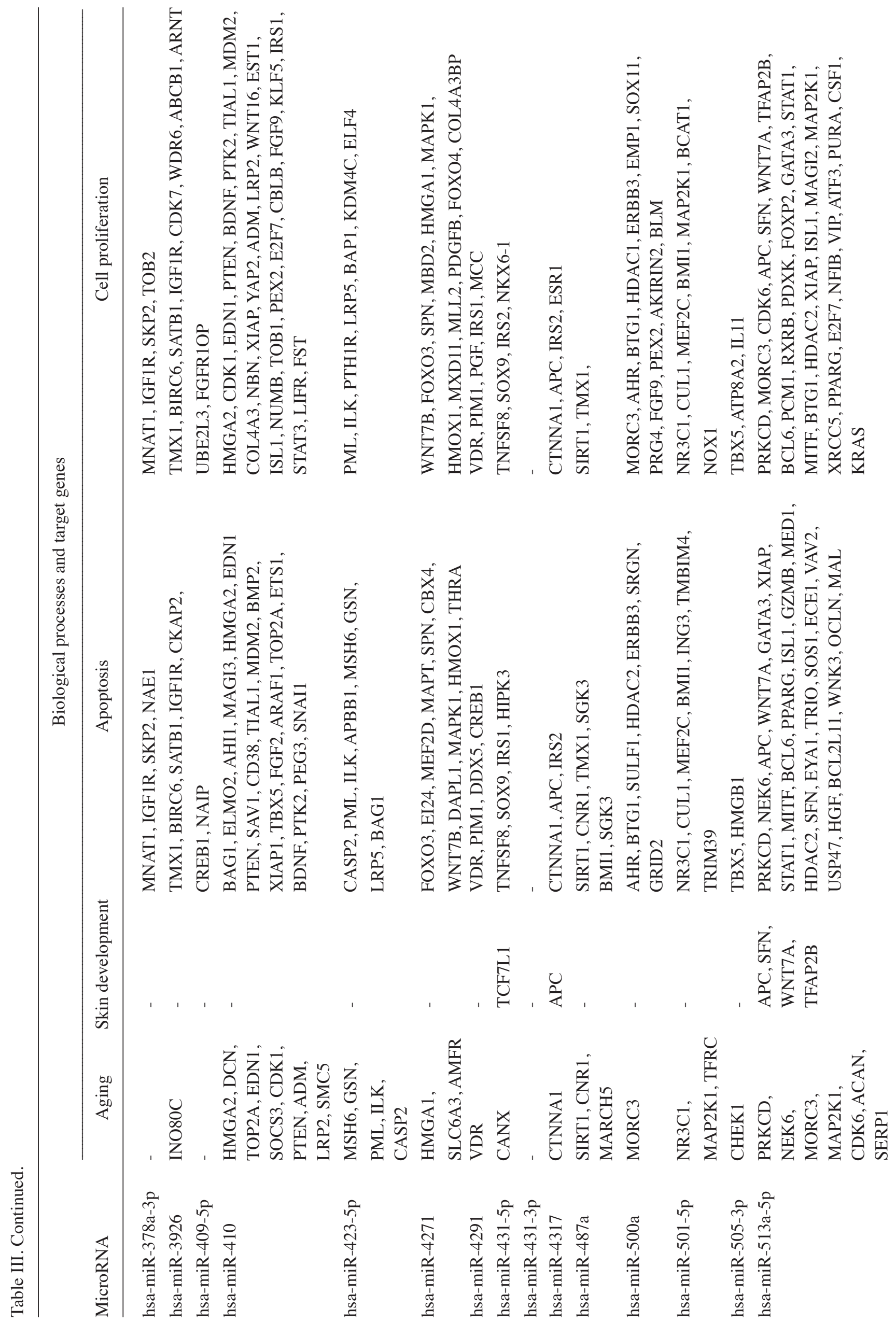




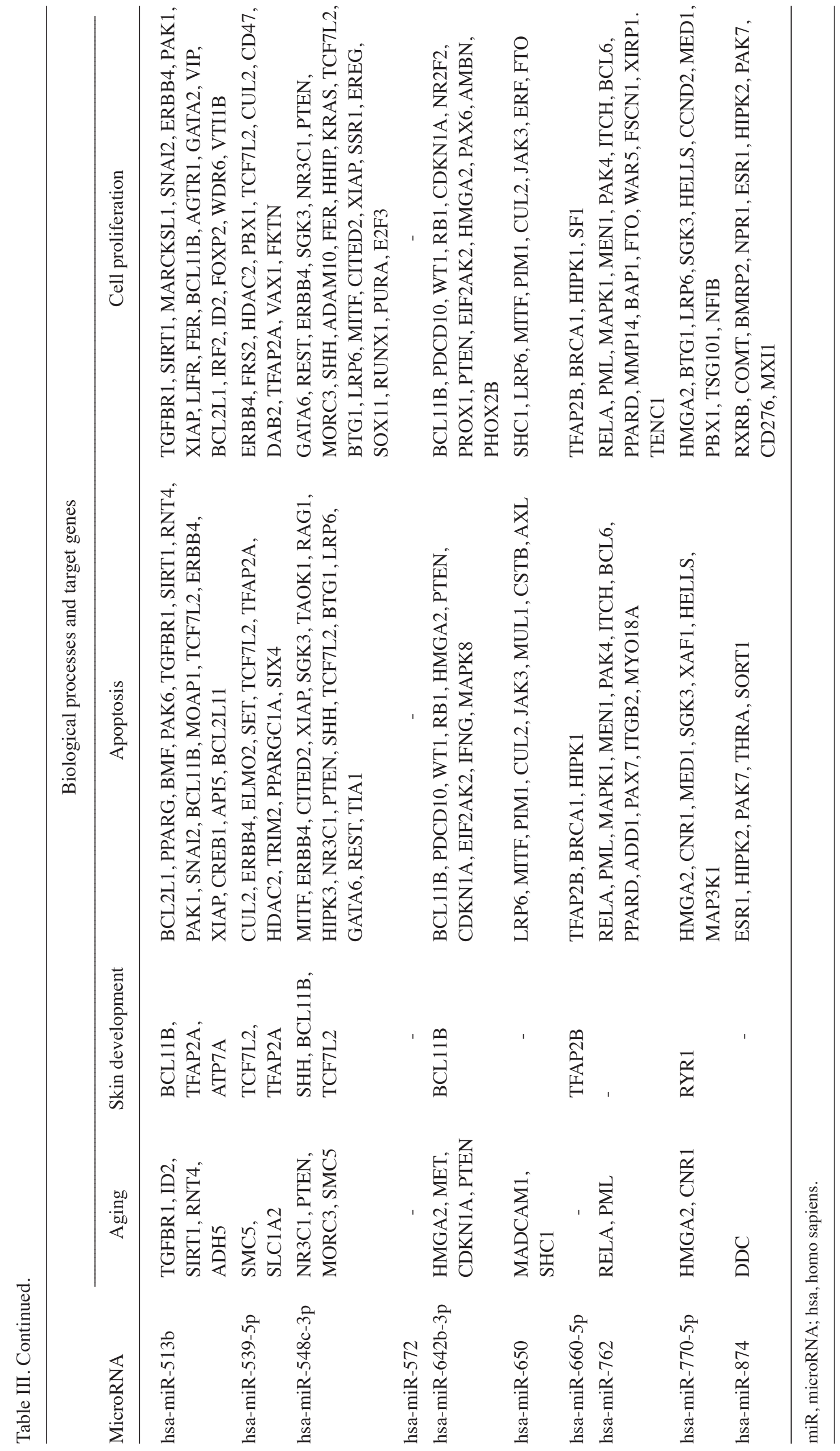


Table IV. Main functions of upregulated microRNAs predicted using bioinformatics analysis.

\begin{tabular}{|c|c|c|c|c|c|}
\hline MicroRNA & $\begin{array}{c}\text { Putative target } \\
\text { genes }\end{array}$ & KEGG pathway & $\begin{array}{l}\text { Genes involved } \\
\text { in the term }\end{array}$ & $\begin{array}{l}\% \text { involved } \\
\text { genes }\end{array}$ & P-value \\
\hline \multirow[t]{5}{*}{ hsa-miR-100-3p } & \multirow[t]{5}{*}{167} & Pathways in cancer & 7 & 4.2 & $1.10 \mathrm{E}-02$ \\
\hline & & Ubiquitin mediated proteolysis & 5 & 3.0 & $8.00 \mathrm{E}-03$ \\
\hline & & Melanogenesis & 4 & 2.4 & $2.00 \mathrm{E}-02$ \\
\hline & & Cell cycle & 4 & 2.4 & $3.60 \mathrm{E}-02$ \\
\hline & & Wnt signaling pathway & 4 & 2.4 & $5.80 \mathrm{E}-02$ \\
\hline \multirow[t]{3}{*}{ hsa-miR-1225-3p } & \multirow[t]{3}{*}{183} & MAPK signaling pathway & 7 & 3.8 & $6.20 \mathrm{E}-02$ \\
\hline & & Neurotrophin signaling pathway & 5 & 2.7 & 4.20E-02 \\
\hline & & Cell adhesion molecules & 5 & 2.7 & $5.10 \mathrm{E}-02$ \\
\hline \multirow[t]{2}{*}{ hsa-miR-1228-3p } & \multirow[t]{2}{*}{198} & Wnt signaling pathway & 4 & 2.0 & $1.30 \mathrm{E}-01$ \\
\hline & & MAPK signaling pathway & 4 & 2.0 & $3.80 \mathrm{E}-01$ \\
\hline hsa-miR-1238 & 130 & - & - & - & - \\
\hline \multirow{2}{*}{ hsa-miR-1825 } & \multirow[t]{2}{*}{321} & Pathways in cancer & 9 & 2.8 & $6.90 \mathrm{E}-02$ \\
\hline & & MAPK signaling pathway & 8 & 2.5 & $6.40 \mathrm{E}-02$ \\
\hline \multirow[t]{3}{*}{ hsa-miR-18b-3p } & \multirow[t]{3}{*}{108} & Long-term potentiation & 4 & 3.7 & $3.80 \mathrm{E}-03$ \\
\hline & & Natural killer cell mediated cytotoxicity & 4 & 3.7 & $2.40 \mathrm{E}-02$ \\
\hline & & Calcium signaling pathway & 4 & 3.7 & $4.80 \mathrm{E}-02$ \\
\hline hsa-miR-191-3p & 11 & - & - & - & - \\
\hline hsa-miR-3180-5p & 489 & - & - & - & - \\
\hline \multirow[t]{2}{*}{ hsa-miR-33b-3p } & \multirow[t]{2}{*}{121} & Neuroactive ligand-receptor interaction & 5 & 4.1 & $6.10 \mathrm{E}-02$ \\
\hline & & Calcium signaling pathway & 4 & 3.3 & $8.40 \mathrm{E}-02$ \\
\hline hsa-miR-425-3p & 8 & - & - & - & - \\
\hline hsa-miR-4286 & 87 & Glycosphingolipid biosynthesis & 2 & 2.3 & $6.30 \mathrm{E}-02$ \\
\hline \multirow[t]{3}{*}{ hsa-miR-4313 } & \multirow[t]{3}{*}{57} & $\begin{array}{l}\text { Arrhythmogenic right ventricular } \\
\text { cardiomyopathy }\end{array}$ & 3 & 5.3 & $2.60 \mathrm{E}-02$ \\
\hline & & Melanogenesis & 3 & 5.3 & 4.20E-02 \\
\hline & & Wnt signaling pathway & 3 & 5.3 & 8.90E-02 \\
\hline \multirow[t]{3}{*}{ hsa-miR-4323 } & \multirow[t]{3}{*}{153} & Axon guidance & 5 & 3.3 & $2.10 \mathrm{E}-02$ \\
\hline & & ErbB signaling pathway & 4 & 2.6 & $3.40 \mathrm{E}-02$ \\
\hline & & GnRH signaling pathway & 4 & 2.6 & $4.60 \mathrm{E}-02$ \\
\hline hsa-miR-634 & 207 & GnRH signaling pathway & 5 & 2.4 & $4.10 \mathrm{E}-02$ \\
\hline \multirow[t]{2}{*}{ hsa-miR-766-3p } & \multirow[t]{2}{*}{357} & Tight junction & 10 & 2.8 & 4.60E-04 \\
\hline & & Viral myocarditis & 8 & 2.2 & $2.00 \mathrm{E}-04$ \\
\hline hsa-miR-933 & 9 & - & - & - & - \\
\hline
\end{tabular}

miR, microRNA; hsa, homo sapiens; KEGG, Kyoto Encyclopedia of Genes and Genomes; MAPK, mitogen-activated protein kinase; GnRH, gonadotropin-releasing hormone.

signaling, oocyte meiosis, glycerolipid metabolism, MAPK signaling, insulin signaling, chemokine signaling, cytokine-cytokine receptor interaction, Janus kinase-signal transducer and activator of transcription signaling, calcium signaling, mammalian target of rapamycin signaling, axon guidance, cell cycle, ubiquitin mediated proteolysis, regulation of actin cytoskeleton, ErbB signaling, melanogenesis, TGF- $\beta$ signaling, vascular smooth muscle contraction, tight junction, neuroactive ligand-receptor interactions, CAMs, glycerophospholipid metabolism, adipocytokine signaling and neurotrophin signaling (Table V).

\section{Discussion}

Although PPD has been widely used in hair dyes and tattoos, previous studies have demonstrated that PPD may be an important etiological factor for allergic contact dermatitis $(20,21)$. However, the side effects of PPD in hair follicle cells remain to be fully elucidated. The results of the current study provided evidence for senescence and cell death as key responses of nHHDPCs to PPD. The senescence-associated alterations observed included $G_{2}$ phase arrest and increases in ROS production as well as SA- $\beta$-gal activity. To the best of 
Table V. Main functions of downregulated microRNAs predicted using bioinformatics analysis.

\begin{tabular}{|c|c|c|c|c|c|}
\hline MicroRNA & $\begin{array}{c}\text { Putative target } \\
\text { genes }\end{array}$ & KEGG pathway & $\begin{array}{l}\text { Genes involved in } \\
\text { the term }\end{array}$ & $\begin{array}{l}\% \text { involved } \\
\text { genes }\end{array}$ & P-value \\
\hline hsa-let-7a-3p & 626 & $\begin{array}{l}\text { Pathways in cancer } \\
\text { Regulation of actin cytoskeleton } \\
\text { Wnt signaling pathway }\end{array}$ & $\begin{array}{l}24 \\
15 \\
13\end{array}$ & $\begin{array}{l}3.8 \\
2.4 \\
2.1\end{array}$ & $\begin{array}{l}4.60 \mathrm{E}-04 \\
1.20 \mathrm{E}-02 \\
4.20 \mathrm{E}-03\end{array}$ \\
\hline hsa-miR-150-3p & 184 & $\begin{array}{l}\text { Wnt signaling pathway } \\
\text { Oocyte meiosis }\end{array}$ & $\begin{array}{l}5 \\
4\end{array}$ & $\begin{array}{l}2.7 \\
2.2\end{array}$ & $\begin{array}{l}6.00 \mathrm{E}-02 \\
9.30 \mathrm{E}-02\end{array}$ \\
\hline hsa-miR-1181 & 2 & - & - & - & - \\
\hline hsa-miR-1207-5p & 503 & $\begin{array}{l}\text { Regulation of actin cytoskeleton, } \\
\text { MAPK signaling pathway }\end{array}$ & $\begin{array}{l}11 \\
11\end{array}$ & $\begin{array}{l}2.2 \\
2.2\end{array}$ & $\begin{array}{l}2.50 \mathrm{E}-02 \\
8.60 \mathrm{E}-02\end{array}$ \\
\hline hsa-miR-1226-5p & 219 & - & - & - & - \\
\hline hsa-miR-125a-3p & 42 & Glycerolipid metabolism & 2 & 4.8 & 7.70E-02 \\
\hline hsa-miR-128 & 642 & $\begin{array}{l}\text { MAPK signaling pathway } \\
\text { Insulin signaling pathway }\end{array}$ & $\begin{array}{l}22 \\
13\end{array}$ & $\begin{array}{l}3.4 \\
2.0\end{array}$ & $\begin{array}{l}1.50 \mathrm{E}-04 \\
1.50 \mathrm{E}-03\end{array}$ \\
\hline hsa-miR-134 & 245 & $\begin{array}{l}\text { Chemokine signaling pathway } \\
\text { Cytokine-cytokine receptor interaction } \\
\text { Jak-STAT signaling pathway } \\
\text { Calcium signaling pathway }\end{array}$ & $\begin{array}{l}7 \\
7 \\
6 \\
6\end{array}$ & $\begin{array}{l}2.9 \\
2.9 \\
2.4 \\
2.4\end{array}$ & $\begin{array}{l}1.70 \mathrm{E}-02 \\
7.10 \mathrm{E}-02 \\
2.90 \mathrm{E}-02 \\
4.60 \mathrm{E}-02\end{array}$ \\
\hline hsa-miR-138-2-3p & 345 & $\begin{array}{l}\text { Pathways in cancer } \\
\text { MAPK signaling pathway }\end{array}$ & $\begin{array}{l}14 \\
11\end{array}$ & $\begin{array}{l}4.1 \\
3.2\end{array}$ & $\begin{array}{l}3.90 \mathrm{E}-03 \\
1.60 \mathrm{E}-02\end{array}$ \\
\hline hsa-miR-146b-5p & 314 & - & - & - & - \\
\hline hsa-miR-148b-3p & 454 & Pathways in cancer & 20 & 4.4 & $5.30 \mathrm{E}-04$ \\
\hline hsa-miR-17-3p & 307 & $\begin{array}{l}\text { MAPK signaling pathway } \\
\text { Pathways in cancer } \\
\text { Insulin signaling pathway } \\
\text { mTOR signaling pathway }\end{array}$ & $\begin{array}{r}10 \\
9 \\
7 \\
6\end{array}$ & $\begin{array}{l}3.3 \\
2.9 \\
2.3 \\
2.0\end{array}$ & $\begin{array}{l}1.30 \mathrm{E}-02 \\
9.60 \mathrm{E}-02 \\
1.20 \mathrm{E}-02 \\
8.20 \mathrm{E}-04\end{array}$ \\
\hline hsa-miR-181d & 286 & Insulin signaling pathway & 6 & 2.1 & $2.10 \mathrm{E}-02$ \\
\hline hsa-miR-185-5p & 423 & Axon guidance & 10 & 2.4 & 5.70E-04 \\
\hline hsa-miR-195-5p & 506 & $\begin{array}{l}\text { Pathways in cancer } \\
\text { MAPK signaling pathway } \\
\text { Wnt signaling pathway } \\
\text { Insulin signaling pathway } \\
\text { Cell cycle } \\
\text { Ubiquitin mediated proteolysis }\end{array}$ & $\begin{array}{l}21 \\
14 \\
13 \\
12 \\
10 \\
10\end{array}$ & $\begin{array}{l}4.2 \\
2.8 \\
2.6 \\
2.4 \\
2.0 \\
2.0\end{array}$ & $\begin{array}{l}1.30 \mathrm{E}-03 \\
4.80 \mathrm{E}-02 \\
1.40 \mathrm{E}-03 \\
1.90 \mathrm{E}-03 \\
1.10 \mathrm{E}-02 \\
1.90 \mathrm{E}-02\end{array}$ \\
\hline hsa-miR-197-3p & 216 & $\begin{array}{l}\text { Ubiquitin mediated proteolysis } \\
\text { Calcium signaling pathway }\end{array}$ & $\begin{array}{l}6 \\
5\end{array}$ & $\begin{array}{l}2.8 \\
2.3\end{array}$ & $\begin{array}{l}1.10 \mathrm{E}-02 \\
9.90 \mathrm{E}-02\end{array}$ \\
\hline hsa-miR-202-3p & 223 & Axon guidance & 5 & 2.2 & 7.80E-02 \\
\hline hsa-miR-214-5p & 196 & Regulation of actin cytoskeleton & 6 & 3.1 & $6.70 \mathrm{E}-02$ \\
\hline hsa-miR-23a-5p & 99 & - & - & - & - \\
\hline hsa-miR-28-5p & 157 & MAPK signaling pathway & 7 & 4.5 & $1.20 \mathrm{E}-02$ \\
\hline hsa-miR-301a-3p & 470 & Regulation of actin cytoskeleton & 13 & 2.8 & $1.30 \mathrm{E}-02$ \\
\hline hsa-miR-30a-3p & 221 & $\begin{array}{l}\text { Pathways in cancer } \\
\text { ErbB signaling pathway }\end{array}$ & $\begin{array}{l}9 \\
5\end{array}$ & $\begin{array}{l}4.1 \\
2.3\end{array}$ & $\begin{array}{l}3.70 \mathrm{E}-02 \\
1.90 \mathrm{E}-02\end{array}$ \\
\hline hsa-miR-30e-3p & 185 & $\begin{array}{l}\text { Pathways in cancer } \\
\text { Jak-STAT signaling pathway } \\
\text { ErbB signaling pathway } \\
\text { Melanogenesis }\end{array}$ & $\begin{array}{l}8 \\
5 \\
4 \\
4\end{array}$ & $\begin{array}{l}4.3 \\
2.7 \\
2.2 \\
2.2\end{array}$ & $\begin{array}{l}5.70 \mathrm{E}-02 \\
8.10 \mathrm{E}-02 \\
6.40 \mathrm{E}-02 \\
8.70 \mathrm{E}-02\end{array}$ \\
\hline hsa-miR-324-5p & 39 & - & - & - & - \\
\hline hsa-miR-342-3p & 386 & $\begin{array}{l}\text { Calcium signaling pathway } \\
\text { TGF- } \beta \text { signaling pathway }\end{array}$ & $\begin{array}{l}9 \\
7\end{array}$ & $\begin{array}{l}2.3 \\
1.8\end{array}$ & $\begin{array}{l}2.60 \mathrm{E}-02 \\
8.00 \mathrm{E}-03\end{array}$ \\
\hline
\end{tabular}


Table V. Continued.

\begin{tabular}{|c|c|c|c|c|c|}
\hline MicroRNA & $\begin{array}{l}\text { Putative target } \\
\text { genes }\end{array}$ & KEGG pathway & $\begin{array}{c}\text { Genes involved in } \\
\text { the term }\end{array}$ & $\begin{array}{l}\% \text { involved } \\
\text { genes }\end{array}$ & P-value \\
\hline hsa hsa-miR-3651 & 57 & - & - & - & - \\
\hline hsa-miR-3653 & 87 & - & - & - & - \\
\hline hsa-miR-3656 & 10 & - & - & - & - \\
\hline hsa-miR-3663-3p & 305 & MAPK signaling pathway & 12 & 3.9 & $5.90 \mathrm{E}-03$ \\
\hline hsa-miR-369-3p & 743 & MAPK signaling pathway & 15 & 2.0 & $9.90 \mathrm{E}-02$ \\
\hline hsa-miR-369-5p & 2 & - & - & - & - \\
\hline \multirow[t]{2}{*}{ hsa-miR-370 } & 260 & Pathways in cancer & 8 & 3.1 & $6.10 \mathrm{E}-02$ \\
\hline & & Chemokine signaling pathway & 6 & 2.3 & $5.00 \mathrm{E}-02$ \\
\hline hsa-miR-371a-5p & 216 & Wnt signaling pathway & 5 & 2.3 & $6.70 \mathrm{E}-02$ \\
\hline hsa-miR-378a-3p & 101 & Pathways in cancer & 7 & 6.9 & $2.00 \mathrm{E}-02$ \\
\hline hsa-miR-3926 & 274 & - & - & - & - \\
\hline hsa-miR-409-5p & 16 & - & - & - & - \\
\hline \multirow[t]{3}{*}{ hsa-miR-410 } & 852 & Pathways in cancer & 29 & 3.4 & 4.80E-04 \\
\hline & & MAPK signaling pathway & 20 & 2.3 & $2.50 \mathrm{E}-02$ \\
\hline & & Wnt signaling pathway & 16 & 2.0 & $2.50 \mathrm{E}-03$ \\
\hline \multirow[t]{3}{*}{ hsa-miR-423-5p } & 218 & Calcium signaling pathway & 6 & 2.8 & $2.20 \mathrm{E}-02$ \\
\hline & & MAPK signaling pathway & 6 & 2.8 & $9.80 \mathrm{E}-02$ \\
\hline & & Insulin signaling pathway & 5 & 2.3 & $3.50 \mathrm{E}-02$ \\
\hline hsa-miR-4271 & 247 & Chemokine signaling pathway & 6 & 2.4 & $9.40 \mathrm{E}-02$ \\
\hline hsa-miR-4291 & 88 & - & - & - & - \\
\hline hsa-miR-431-5p & 172 & Wnt signaling pathway & 5 & 2.9 & $2.70 \mathrm{E}-02$ \\
\hline hsa-miR-431-3p & 2 & - & - & - & - \\
\hline hsa-miR-4317 & 67 & Vascular smooth muscle contraction & 3 & 4.5 & $9.00 \mathrm{E}-02$ \\
\hline \multirow[t]{2}{*}{ hsa-miR-487a } & 184 & MAPK signaling pathway & 7 & 3.8 & 4.90E-02 \\
\hline & & Tight junction & 6 & 3.3 & $1.00 \mathrm{E}-02$ \\
\hline hsa-miR-500a & 260 & Ubiquitin mediated proteolysis & 7 & 2.0 & $8.50 \mathrm{E}-02$ \\
\hline hsa-miR-501-5p & 179 & Ubiquitin mediated proteolysis & 6 & 3.4 & $8.20 \mathrm{E}-03$ \\
\hline hsa-miR-505-3p & 30 & - & - & - & - \\
\hline \multirow[t]{4}{*}{ hsa-miR-513a-5p } & 773 & Pathways in cancer & 24 & 3.1 & $2.00 \mathrm{E}-02$ \\
\hline & & MAPK signaling pathway & 20 & 2.6 & $2.80 \mathrm{E}-02$ \\
\hline & & Focal adhension & 18 & 2.3 & 7.90E-03 \\
\hline & & Regulation of actin cytoskeleton & 17 & 2.2 & $3.00 \mathrm{E}-02$ \\
\hline hsa-miR-513b & 557 & Neuroactive ligand-receptor interaction & 12 & 2.2 & $8.60 \mathrm{E}-02$ \\
\hline hsa-miR-539-5p & 340 & - & - & - & - \\
\hline \multirow[t]{3}{*}{ hsa-miR-548c-3p } & 438 & Pathways in cancer & 17 & 3.9 & $2.20 \mathrm{E}-03$ \\
\hline & & Wnt signaling pathway & 12 & 2.7 & 4.70E-04 \\
\hline & & Insulin signaling pathway & 9 & 2.1 & $9.90 \mathrm{E}-03$ \\
\hline hsa-miR-572 & 4 & - & - & - & - \\
\hline \multirow[t]{2}{*}{ hsa-miR-642b-3p } & 180 & Pathways in cancer & 7 & 3.9 & $4.60 \mathrm{E}-02$ \\
\hline & & Cell adhesion molecules & 5 & 2.8 & $2.10 \mathrm{E}-02$ \\
\hline hsa-miR-650 & 151 & Glycerophospholipid metabolism & 3 & 2.0 & $9.90 \mathrm{E}-02$ \\
\hline hsa-miR-660-5p & 104 & Adipocytokine signaling pathway & 3 & 2.9 & 7.70E-02 \\
\hline \multirow[t]{4}{*}{ hsa-miR-762 } & 342 & Axon guidance & 10 & 2.9 & 3.80E-04 \\
\hline & & MAPK signaling pathway & 9 & 2.6 & $9.40 \mathrm{E}-02$ \\
\hline & & Cell adhesion molecules (CAMs) & 7 & 2.0 & $2.70 \mathrm{E}-02$ \\
\hline & & Cell adhesion molecules (CAMs) & 7 & 2.0 & $2.70 \mathrm{E}-02$ \\
\hline
\end{tabular}


Table V. Continued.

\begin{tabular}{|c|c|c|c|c|c|}
\hline MicroRNA & $\begin{array}{c}\text { Putative target } \\
\text { genes }\end{array}$ & KEGG pathway & $\begin{array}{l}\text { Genes involved in } \\
\text { the term }\end{array}$ & $\begin{array}{l}\% \text { involved } \\
\text { genes }\end{array}$ & P-value \\
\hline \multirow[t]{2}{*}{ hsa-miR-770-5p } & 171 & Neurotrophin signaling pathway & 6 & 3.5 & $4.00 \mathrm{E}-03$ \\
\hline & & MAPK signaling pathway & 6 & 3.5 & 7.90E-02 \\
\hline hsa-miR-874 & 99 & - & - & - & - \\
\hline
\end{tabular}

miR, microRNA; hsa, homo sapiens; KEGG, Kyoto Encyclopedia of Genes and Genomes; MAPK, mitogen-activated protein kinase; Jak-STAT, Janus kinase-signal transducer and activator of transcription; mTOR, mammalian target of rapamycin; TGF- $\beta$, transforming growth factor- $\beta$.

our knowledge, the present study was to first to report these responses in dermal papilla cells, although PPD-mediated hair loss has been described in a clinical report (10). PPD was reported to promote apoptosis through oxidative stress-induced DNA damage in kidney and liver cells $(22,23)$. The data of the current study confirmed the apoptotic effect of PPD in dermal papilla cells; however, maximal toxicity was obtained at $600 \mu \mathrm{M}$, which only increased the proportion of apoptotic cells $9.21 \%$. The most notable observation in the present study was the implication of PPD in the induction of $G_{2}$ phase arrest, cellular ROS production and senescence in dermal papilla cells. The proportion of cells in $\mathrm{G}_{1} / \mathrm{G}_{2}$ phase was significantly reduced at $400 \mu \mathrm{M}$, at which concentration ROS production was increased by $50.61 \%$ compared with the control group. Consistent with the data described, $400 \mu \mathrm{M}$ PPD increased the number of senescent cells by $15.90 \%$. It has been previously demonstrated that PPD increased intracellular ROS levels and induced apoptosis in Chang normal human liver cells (8). In the present study, marked alterations in the levels of cell death and senescence were observed in dermal papilla cells following PPD treatment. The data collected indicated that PPD induced $\mathrm{G}_{2}$ arrest and ROS production, which in turn triggered cellular senescence leading to cell death in HHDPCs.

Under identical experimental conditions, the present study identified 74 miRNAs that were differentially expressed by $\geq 2$-fold following PPD treatment in nHHDPCs. Among these, 16 miRNAs were significantly upregulated and 58 miRNAs were significantly downregulated in PPD-treated nHHDPCs. Of note, the expression levels of miR-146b-5p were significantly downregulated by 30.17-fold following PPD treatment of the cells. miR-146b-5p has been previously reported to negatively regulate cellular senescence via targeting interleukin-1 receptor-associated kinase 1 in fibroblasts (24). In addition, miR-378, which was downregulated by 36.78 -fold in the present study, has been previously reported to promote cell survival, tumor growth and angiogenesis through targeting suppressor of fused and fused in sarcoma-1 (25). Together, miR-146b-5p and miR-378 are known to be critical miRNAs involved in cell survival and anti-senescence; thus, regulation of their expression is a promising strategy for the treatment of PPD-mediated cellular senescence in dermal papilla cells. The biological functions of potential target genes of the altered miRNAs were further demonstrated using GO analysis and the web-based program DAVID. The target genes were categorized into four GO terms: Aging, skin development, apoptosis and cell proliferation. Additionally, KEGG pathway analysis identified that the target genes of the miRNAs upregulated by PPD treatment were predominantly implicated in the Wnt and MAPK signaling pathways. The Wnt signaling pathway has been demonstrated to maintain the balance between cell proliferation and differentiation (26). Notably, the Wnt signaling pathway has an important involvement in hair follicle morphogenesis via activation of $\beta$-catenin (27). In addition, in bald patients, activation of Wnt signaling was reported to induce reactivation of hair growth (28). Therefore, the results of the KEGG pathway analysis in the present study indicated that PPD regulated hair growth, morphogenesis and proliferation of dermal papilla cells via miRNA-mediated regulation of the Wnt signaling pathway. MAPKs are important intracellular signaling molecules which have pivotal roles in proliferation, differentiation, development, transformation and apoptosis (29). Therefore, the results of the present study suggested that PPD regulated MAPK signaling pathways through altering the expression of specific miRNAs, which in turn altered cell proliferation in dermal papilla cells.

In conclusion, to the best of our knowledge the present study was the first to use cell-based assays and miRNA microarray analysis to demonstrate that PPD significantly induced dermal papilla cell death and senescence through alteration of the expression levels of specific miRNAs. The results of the current study also suggested that the identified miRNAs may be potential candidates for the development of novel treatment strategies for PPD-induced cell dysfunction.

\section{Acknowledgements}

The current study was supported by a grant from the Korean Health Technology R\&D Project, Ministry of Health \& Welfare, Republic of Korea (grant no. HN13C0075). Dr Seunghee Bae was additionally supported by the KU Research Professor Program of Konkuk University.

\section{References}

1. Anderson JS: The chemistry of hair colorants. Colorant Tech 116: 193-196, 2000.

2. Corbett JF: An historical review of the use of dye precursors in the formulation of commercial oxidation hair dyes. Dyes Pigments 41: 127-136, 1999.

3. Tukenmez Demirci G, Kivanc Altunay I, Atis G and Kucukunal A: Allergic contact dermatitis mimicking angioedema due to paraphenylendiamine hypersensitivity: a case report. Cutan Ocul Toxicol 31: 250-252, 2012.

4. Marcoux D, Couture-Trudel PM, Riboulet-Delmas G and Sasseville D: Sensitization to para-phenylenediamine from a streetside temporary tattoo. Pediatr Dermatol 19: 498-502, 2002. 
5. Coulter EM, Farrell J, Mathews KL, Maggs JL, Pease CK, Lockley DJ, Basketter DA, Park BK and Naisbitt DJ: Activation of human dendritic cells by p-phenylenediamine. J Pharmacol Exp Ther 320: 885-892, 2007.

6. Rojanapo W, Kupradinun P, Tepsuwan A, Chutimataewin S and Tanyakaset M: Carcinogenicity of an oxidation product of p-phenylenediamine. Carcinogenesis 7: 1997-2002, 1986.

7. Sontag JM: Carcinogenicity of substituted-benzenediamines (phenylenediamines) in rats and mice. J Natl Cancer Inst 66: 591-602, 1981.

8. Chye SM, Tiong YL, Yip WK, Koh RY, Len YW, Seow HF, $\mathrm{Ng}$ KY, Ranjit DA and Chen SC: Apoptosis induced by para-phenylenediamine involves formation of ROS and activation of p38 and JNK in chang liver cells. Environ Toxicol 29: 981-990, Nov 22, 2014 [Epub ahead of print].

9. Huang YC, Hung WC, Chye SM, Chen WT and Chai CY para-Phenylenediamine-induced autophagy in human uroepithelial cell line mediated mutant p53 and activation of ERK signaling pathway. Toxicol In Vitro 25: 1630-1637, 2011.

10. Ishida W, Makino T and Shimizu T: Severe hair loss of the scalp due to a hair dye containing para phenylenediamine. ISRN Dermatol 2011: 947284, 2011.

11. Bartel DP: MicroRNAs: genomics, biogenesis, mechanism and function. Cell 116: 281-297, 2004.

12. Carrington JC and Ambros V: Role of microRNAs in plant and animal development. Science 301: 336-338, 2003.

13. Wan G, Mathur R, Hu X, Zhang X and Lu X: miRNA response to DNA damage. Trends Biochem Sci 36: 478-484, 2011.

14. Mardaryev AN, Ahmed MI, Vlahov NV, Fessing MY, Gill JH, Sharov AA and Botchkareva NV: Micro-RNA-31 controls hair cycle-associated changes in gene expression programs of the skin and hair follicle. FASEB J 24: 3869-3881, 2010.

15. Amelio I, Lena AM, Bonanno E, Melino G and Candi E: miR-24 affects hair follicle morphogenesis targeting Tcf-3. Cell Death Dis 4: e922, 2013

16. Andl T, Murchison EP, Liu F, Zhang Y, Yunta-Gonzalez M, Tobias JW, Andl CD, Seykora JT, Hannon GJ and Millar SE: The miRNA-processing enzyme dicer is essential for the morphogenesis and maintenance of hair follicles. Curr Biol 16: 1041-1049, 2006

17. Coulter EM, Farrell J, Mathews KL, Maggs JL, Pease CK, Lockley DJ, Basketter DA, Park BK and Naisbitt DJ: Activation of human dendritic cells by p-phenylenediamine. J Pharmacol Exp Ther 320: 885-892, 2007.
18. So Y, Shin C, Song M, Rha Y and Ryu J: Gene expression profiling of hair-dying agent, para-phenylenediamine, in human keratinocytes $(\mathrm{HaCaT})$ cells. Mol Cell Toxicol 7: 339-346, 2011.

19. Colavitti R and Finkel T: Reactive oxygen species as mediators of cellular senescence. IUBMB Life 57: 277-281, 2005.

20. Akelma AZ, Cizmeci MN, Sarifakioglu E and Mete E: A child with allergic contact dermatitis due to para-phenylenediamine. J Allergy Clin Immunol Pract 1: 399-400, 2013.

21. Goebel C, Troutman J, Hennen J, Rothe H, Schlatter H, Gerberick GF and Blömeke B: Introduction of a methoxymethyl side chain into $\mathrm{p}$-phenylenediamine attenuates its sensitizing potency and reduces the risk of allergy induction. Toxicol Appl Pharmacol 274: 480-487, 2014.

22. Chen SC, Chen CH, Chern CL, Hsu LS, Huang YC, Chung KT and Chye SM: p-Phenylenediamine induces p53-mediated apoptosis in Mardin-Darby canine kidney cells. Toxicol In Vitro 20: 801-807, 2006

23. Chen SC, Chen CH, Tioh YL, Zhong PY, Lin YS and Chye SM: Para-phenylenediamine induced DNA damage and apoptosis through oxidative stress and enhanced caspase- 8 and -9 activities in Mardin-Darby canine kidney cells. Toxicol In Vitro 24: 1197-1202, 2010

24. Bhaumik D, Scott GK, Schokrpur S, Patil CK, Orjalo AV, Rodier F, Lithgow GJ and Campisi J: MicroR NAs miR-146a/b negatively modulate the senescence-associated inflammatory mediators IL-6 and IL-8. Aging (Albany NY) 1: 402-411, 2009.

25. Lee DY, Deng Z, Wang CH and Yang BB: MicroRNA-378 promotes cell survival, tumor growth and angiogenesis by targeting $\mathrm{SuFu}$ and Fus-1 expression. Proc Natl Acad Sci USA 104: 20350-20355, 2007.

26. Teo JL and Kahn M: The Wnt signaling pathway in cellular proliferation and differentiation: A tale of two coactivators. Adv Drug Deliv Rev 62: 1149-1155, 2010.

27. Huelsken J, Vogel R, Erdmann B, Cotsarelis G and Birchmeier W: beta-Catenin controls hair follicle morphogenesis and stem cell differentiation in the skin. Cell 105: 533-545, 2001.

28. Beaudoin GM III, Sisk JM, Coulombe PA and Thompson CC: Hairless triggers reactivation of hair growth by promoting Wnt signaling. Proc Natl Acad Sci USA 102: 14653-14658, 2005.

29. Zhang W and Liu HT: MAPK signal pathways in the regulation of cell proliferation in mammalian cells. Cell Res 12 9-18, 2002 . 